IRSH 50 (2005), pp. 27-5 I DOI: I0.I0I7/S002085900400I $84 \mathrm{I}$

(C) 2005 Internationaal Instituut voor Sociale Geschiedenis

\title{
Organizing a Labor Law Violator: The J.P. Stevens Campaign and the Struggle to Unionize the US South, I $963-1983$
}

\author{
Timothy J. Minchin
}

Summary: Between I963 and I983, unions in the US launched a major campaign to try to organize J.P. Stevens, the nation's second-largest textile firm. Labor leaders felt that if they could organize Stevens, other gains in the nonunion South would follow. Stevens resisted the campaign by firing and intimidating union supporters, repeatedly breaking labor laws in the process. This article examines the union's organizing efforts and argues that the campaign's failure was not due simply to the company's lawlessness. In particular, the influx of African Americans into the workforce had an important impact on organizing. While African Americans did respond enthusiastically to the union, their activism tended to scare off whites, and the union struggled to build effective interracial unions. Other factors, such as the company's willingness to match union wage rates and the economic decline of the textile industry, also prevented the union from making more progress.

In the spring of 1963 , leaders of the Textile Workers' Union of America (TWUA) selected J.P. Stevens, the nation's second-largest textile company, as their target for a major organizing campaign. The company ran over sixty plants in the South, and union leaders reasoned that if they could break through at such a large firm, widespread gains in the nonunion region would follow. Stevens, however, bitterly resisted the union's efforts, often breaking labor laws in the process. Between 1965 and I976, the company was cited for violating the National Labor Relations Act (NLRA) in fifteen different cases, paying out around \$I.3 million in back pay to approximately 300 workers. ${ }^{I}$ Despite these setbacks, the TWUA fought on, feeling that they could not allow such lawlessness to prevail. In the late I970s, the union launched a boycott and corporate campaign

I. Testimony of the Textile Workers' Union of America Before the House of Representatives Committee on Education and Labor, Subcommittee on Labor-Management Relations, is March 1976; "House Subcommittee" folder, box 390, Amalgamated Clothing and Textile Workers' Union Papers, held at the Kheel Center for Labor-Management Documentation and Archives, School of Industrial and Labor Relations, Cornell University, [hereafter, ACTWU Papers-Cornell]. 
against Stevens, attracting national publicity and backing from a wide range of activist groups, including the National Association for the Advancement of Colored People and the National Organization for Women. At the same time, the union intensified its organizing efforts, and they continued until the two sides finally reached a truce agreement in the fall of 1983. The Stevens campaign was fully backed by the national American Federation of Labor-Congress of Industrial Organizations (AFL-CIO), which came to see the textile giant as a symbol of corporations' willingness to break the law rather than deal with unions. Effectively castigating Stevens as "the nation's No. I labor law violator", AFL-CIO leaders viewed the fight as a test case. As AFL-CIO official James Sala commented, “As long as we've got J.P. Stevens, we'll never really succeed in organizing the South. Not because of textiles, but because of the example it sets for this kind of resistance."

For more than three decades before the Stevens campaign, labor leaders in the US had tried to organize workers in the southern states, where rates of unionization lagged behind the rest of the country. In the I930s, southern employers had resolutely refused to recognize the burgeoning labor movement, and by the end of the decade only 10.7 per cent of southern workers belonged to unions, compared to $2 \mathrm{I}$. 5 per cent in the rest of the US. Helped by both the labor shortage and the protection afforded them by the National War Labor Board, unions made significant gains across the country during World War II, but their progress in the South was again limited. Immediately after the war, a confident CIO launched "Operation Dixie", but the high-profile effort faltered because of employer opposition, racial divisions among the work force, and the growing conservatism of the McCarthy era. By the early I950s, nearly 40 per cent of American workers belonged to unions, but in the South this figure was less than 17 per cent. ${ }^{3}$

Organizing the South became a central priority for the AFL-CIO, created in 1955 following the merger of the American Federation of Labor and the CIO. Federation leaders recognized that the presence of a nonunion South was a major threat to their existence because organized companies could easily relocate in the region. Throughout the i950s and

2. Sala quoted in David Leonhardt, "James Finley, Textile Executive, Dies at 86", New York Times, Io April 2003, printed from NYTimes.com; Proceedings of the First Constitutional Convention of the Amalgamated Clothing and Textile Workers' Union, 25-29 September 1978, p. 200.

3. Gavin Wright, Old South, New South: Revolutions in the Southern Economy since the Civil War (New York, I986), p. 2 18; Michelle Brattain, "The Pursuits of Post-exceptionalism: Race, Gender, Class, and Politics in the New Southern Labor History”, in Glenn T. Eskew (ed.), Labor in the Modern South (Athens, GA, 200I), p. 5. For an exploration of the reasons for the failure of Operation Dixie, see Barbara S. Griffith, The Crisis of American Labor: Operation Dixie and the Defeat of the CIO (Philadelphia, PA, I988). 
I960s, the rate of economic growth in the South was higher than in the US as a whole, and many firms fled to Dixie in order to avoid dealing with organized labor. In I 957, AFL-CIO leader Ben Segal wrote his colleagues that, "No one will deny that the South today, as it was fifteen years ago, is organized labor's number one regional problem." In I959, the AFL-CIO held its first national organizing conference and devoted particular attention to the South. "The need for more organizing effort in the South has never been more pressing", concluded the gathering. "if an unrelenting program of organizational effort is not maintained there by the American labor movement, resulting finally in successful widespread organization, our labor movement will weaken."4

Union leaders recognized that if they were to conquer the region, they had to organize the textile industry, by far its largest employer. In 1973, the industry dwarfed all others in size, employing nearly 700,000 southerners. Other AFL-CIO unions contributed a considerable amount of funding to the Stevens effort, which was spearheaded by the federation's Industrial Union Department (IUD). In the course of the prolonged campaign, the labor movement spent more than $\$ 30$ million in all. Given the scale of expenditure, the results were disappointing, as organizers were only able to bring around 7 per cent of the company's workers into the union fold. They did, however, achieve a symbolic victory in pushing an intransigent employer to accept a limited union presence in its southern plants. ${ }^{5}$

Despite the importance of the Stevens campaign, it has failed to receive a great deal of historical attention. At the time, the drive was well covered by investigative journalists such as Mimi Conway and Ed McConville, but since it faded from the headlines it has received little coverage. ${ }^{6}$ The campaign has been largely bypassed by the recent upsurge in southern

4. Benjamin D. Segal, "Industrialization: Accent on the South", n.d., box 56, "South" folder, AFL-CIO pamphlets; "Number One Objective: A Report of the First AFL-CIO National Organizing Conference", 6-7 January 1959, box 8, “AFL-CIO Organizing Department” folder, AFL-CIO Pamphlets, p. 38 .

5. Timothy J. Minchin, Hiring the Black Worker: The Racial Integration of the Southern Textile Industry, I960-1980 (Chapel Hill, NC, I999), p. 9; Warren Brown, "Great Labor War Gains Tallied”, The Washington Post, 26 October I980, p. A I 4; Judith Schoolman, "Stevens' Pact Irks Some Dixie Mill Men", Daily News Record, 2 I October 1980, clipping in "J.P. Stevens and Company Incorporated General Labor, 1980-8 I" folder, box 677, ACTWU Papers-Cornell. 6. Mimi Conway, Rise Gonna Rise: A Portrait of Southern Textile Workers (Garden City, NY, 1979); Ed McConville, “The Southern Textile War", The Nation, 2 October 1976, pp. 294-299. The campaign attracted considerable attention from newspapers and magazines. Other major articles include Walter Guzzardi, Jr, "How the Union Got the Upper Hand on J.P. Stevens", Fortune, I9 June 1978, pp. 86-89, 91, 94, 98; Peter Kovler, "The South: The Last Bastion of the Open Shop", Politics Today (March-April I979), pp. 26-3 I. 
labor history, even though most studies have concentrated on textiles. ${ }^{7}$ There have been some brief reflective treatments of the struggle, but no systematic analysis of the union's organizing efforts. ${ }^{8}$ Drawing on underutilized archival records, including the union's own organizing reports, it is possible to probe these efforts in greater depth. ${ }^{9}$ These records graphically highlight how Stevens relied heavily on mass discharges of union activists and intimidation in order to see off organized labor. At the same time, there were other reasons for the union's failure that have not been sufficiently recognized. As well as firing and intimidating union supporters, for example, the company also undermined the union's economic appeal by matching union pay scales, a tactic that it used increasingly in the I970s. In the late I970s, organizing efforts were also

7. The growth of Southern labor history has been particularly influenced by Jacquelyn Dowd Hall, James Leloudis, Robert Korstad, Mary Murphy, Lu Ann Jones, and Christopher B. Daly, Like A Family: The Making of a Southern Cotton Mill World (Chapel Hill, NC, 1987), which effectively challenged the stereotype of the passive southern worker, instead highlighting how southern textile workers in the early twentieth century effectively crafted a distinctive culture of their own. Other important works include James A. Hodges, New Deal Labor Policy and the Southern Cotton Textile Industry, I933-I94I (Knoxville, TN, I986); David L. Carlton, Mill and Town in South Carolina, I880-I920 (Baton Rouge, LA, I982); Griffith, The Crisis of American Labor; Michael K. Honey, Southern Labor and Black Civil Rights: Organizing Memphis Workers (Urbana, IL, I993); and Bryant Simon, A Fabric of Defeat: The Politics of South Carolina's Millhands in State and Nation (Chapel Hill, NC, 1998). For a selection of recent scholarship, see Robert H. Zieger (ed.), Organized Labor in the Twentieth-Century South (Knoxville, TN, I99I); idem (ed.), Southern Labor in Transition, 1940-1995 (Knoxville, TN, 1997); Eskew, Labor in the Modern South. Case studies of textile communities include: Douglas Flamming, Creating The Modern South: Millhands and Managers in Dalton, Georgia, I8841984 (Chapel Hill, NC, I992); Daniel J. Clark, Like Night and Day: Unionization in a Southern Mill Town (Chapel Hill, NC, I997); G.C. Waldrep, III, Southern Workers and the Search for Community: Spartanburg County, South Carolina (Urbana, IL, 2000); and Michelle Brattain, The Politics of Whiteness: Race, Workers, and Culture in the Modern South (Princeton, NJ, 200I).

8. James A. Hodges has provided a short, useful summary of the campaign. See James A. Hodges, "J.P. Stevens and the Union: Struggle for the South", in Gary M. Fink and Merl E. Reed (eds), Race, Class, and Community in Southern Labor History (Tuscaloosa, AL, I994), pp. 5364, 246-249. The Stevens campaign is also covered briefly in Barry E. Truchil, Capital-Labor Relations in the US Textile Industry (New York, I988), pp. I39-142; Phillip J. Wood, Southern Capitalism: The Political Economy of North Carolina, I880-1980 (Durham, NC, 1986), pp. I 82-I86; and Richard Rowan and Robert E. Barr, Employee Relations Trends and Practices in the Textile Industry (Philadephia, PA, 1987), pp. 79-82.

9. This account draws chiefly on two collections of papers deposited by ACTWU. The collections, which are both recent additions that are unprocessed, are held at the Southern Labor Archives, Georgia State University, and at the Kheel Center for Labor-Management Documentation and Archives at Cornell University (cited above). Both contain a great deal of material on the union's efforts to organize Stevens that has not been utilized. The papers of the TWUA, held at the State Historical Society of Wisconsin (SHSW) in Madison, are processed and have been more extensively utilized, although the Stevens part of the collection has not been heavily mined. 
hurt by the failure of AFL-CIO efforts to secure labor law reform, and by the launching of the boycott against the company.

In particular, however, the changing racial composition of the southern textile work force had an important impact on organizing efforts. In I960, only 3.3 per cent of southern textile workers were black, but by 1978 this had risen to 25 per cent. Pushed by both civil rights laws and a labor shortage, southern textile executives hired an unprecedented number of African Americans. Over the course of the twenty-year campaign, the proportion of black workers in Stevens's plants increased more than fivefold. In the early i960s, blacks were confined to a small range of menial, nonproduction jobs and made up less than 5 per cent of the company's work force, but by the late i 970 s they filled one-quarter of all jobs at the textile giant. At many of Stevens's plants, African-American workers responded enthusiastically to the union campaign. Black activism was also problematic for the union, however, because it tended to scare off white workers, who often viewed the union as a "black" organization. In the late I970s, organizers complained repeatedly that whites were more reluctant to join the union than blacks were. ${ }^{10}$

Like many companies with textile plants in the South, J.P. Stevens was a northern firm. The firm's origins date back to I8I3, when Nathaniel Stevens had established a fledgling woolen mill in Massachusetts. Through Nathaniel's diligence, the firm survived and expanded, and when he died in I 865 the business was taken over by his son Moses. Another family member, John P. Stevens, pioneered the company's moves into merchandizing, and by World War I, J.P. Stevens was selling the output from nine cotton mills through its Manhattan office. In September 1946, the company went public, the selling house and mill company merging together with eight other companies. Under the chairmanship of Robert T. Stevens, the company began to close its northern mills and move south, attracted by the region's lower wages and weaker unions. Between I947 and 1963 , J.P. Stevens liquidated four northern mills and established eight new plants in the South. In 1963, the average wage in the company's southern plants was \$1.55 an hour, but in New England it was \$1.72. As Fortune magazine noted, by closing its organized northern plants Stevens had "said goodbye to the unions". ${ }^{\text {I }}$

Stevens's southern plants were part of a growing number of "runaway shops" that caused grave problems for textile unions. In the I930s and I940s, the TWUA, like many unions, had made major progress in signing up northern workers but had not been able to make significant progress in the South. Southern workers had shown their willingness to engage in

ı. J.P. Stevens Annual Report 1977, "J.P. Stevens and Company Inc. Annual Reports, I967198 I" folder, box 677, ACTWU Papers-Cornell; Minchin, Hiring the Black Worker, p. 3.

I I. Richard J. Whalen, “The Durable Threads of J.P. Stevens”, Fortune (April I963), pp. Io6I08, 108 . 
labor protest yet corporate opposition had prevented many stable unions from being established in the region. A general strike in I 934 had been bitterly crushed, with many union supporters subsequently blacklisted. ${ }^{12}$ After World War II, Operation Dixie concentrated heavily on textiles but yielded few gains. By the time of the Stevens campaign, fewer than Io per cent of southern textile workers were organized, compared to around 40 per cent of their counterparts in New England, the industry's birthplace. At the same time, the South was home to over 90 per cent of all US cotton mills, many of which had relocated from the north. Between I954 and 1963, the TWUA lost 42,820 members because of the closure of organized northern mills. Union leaders constantly worried about the growth of the unorganized South and the threat that it posed to their northern members. "We have the problem of competing with the non-union South which can do whatever it wants in production processes and hours", noted Amalgamated Clothing and Textile Workers' Union (ACTWU) President Murray Finley at the height of the Stevens campaign. ${ }^{\mathrm{I}}$

This threat pushed union leaders to continue to fund major organizing efforts in Dixie. In the early summer of 1963 , twenty-six organizers headed south to work on the Stevens campaign. Twelve came from the TWUA, while the IUD supplied the rest. Organizers concentrated their efforts on three locations: Roanoke Rapids, North Carolina, and the South Carolina towns of Greenville and Rock Hill. In each location, Stevens had clusters of mills, and strategists argued that they could make rapid gains in these areas. ${ }^{I 4}$ The union had also picked out Stevens because it was a major textile firm. In 1966, the textile giant employed over 43,000 workers, the bulk of them in its seventy southern plants, and leaders reasoned that if Stevens was organized, other gains would soon follow. ${ }^{\text {IS }}$ Stevens was picked out as an "organizing symbol", recalled TWUA executive board

I2. For the 1934 General Textile Strike, see Janet Irons, Testing the New Deal: The General Textile Strike of 1934 in the American South (Urbana, IL, 2000); John A. Salmond, The General Textile Strike of 1934: From Maine to Alabama (Columbia, MO, 2002). For the broader history of textile unionism, see Clete Daniel, Culture of Misfortune: An Interpretative History of Textile Unionism in the United States (Ithaca, NY, 200I).

I3. Griffith, The Crisis of American Labor, pp. I2-21, 46-6I, I6I-76; "Large TWUA Mills Liquidated Since 1954", November 1963, "Research Department 1963" folder, box 625, MSS 396, TWUA Papers, held at the State Historical Society of Wisconsin (SHSW) in Madison, [hereafter “TWUA Papers"]; George A. Kelly, “The J.P. Stevens Boycott: Is It Having an Effect?”, I 4 May 1979, "J.P. Stevens" folder, box 104, ACTWU Papers-Cornell, pp. 4, 7; General Executive Board Meeting, I 2 June 1978, “6/12/78” folder, box 854, ACTWU Papers-Cornell.

I4. Hodges, "J.P. Stevens and the Union", p. 56; "Committee to Work on Selecting Target for IUD Organizing Drive", 24 April I963; and John Chupka to William Pollock, I 3 February I963, both in "Decision to Begin J.P. Stevens Campaign - I963" folder, box 627, ACTWU PapersCornell.

I 5. John Chupka to William Pollock, I3 February 1963, "Decision to Begin J.P. Stevens Campaign - 1963" folder; J.P. Stevens and Co., Inc. Annual Report 1967, “J.P. Stevens and Company, Inc. Annual Reports - 1967-1981”, p. 3. 
member Wesley Cook. "The general feeling was that if you could crack any one of the top half dozen, it would result in making inroads in most of the rest of them", he explained. ${ }^{16}$

It was in the early stages of the campaign that Stevens relied heavily on its classic tactics of openly violating labor laws in order to defeat organizing efforts. In the first four months of the drive, sixty-nine workers were illegally discharged for union activities. ${ }^{17}$ National Labor Relations Board (NLRB) Trial Examiner, Horace A. Ruckel, found that Stevens had committed "massive and deliberate unfair labor practices", engaging in a "systematic attempt to rid itself of union adherents". ${ }^{18}$ Adopting the Board's conclusion, in 1967 the Second Circuit Court of Appeals found the evidence of illegal anti-union activity to be "overwhelming", asserting that Stevens had violated employees' rights "flagrantly, cynically, and unlawfully". ${ }^{9}$

Individual cases highlight well how managers were willing to fire experienced workers on flimsy pretexts in order to kill organizing efforts. At its plant in Whitmire, South Carolina, the company discharged Jess Cudd, a sixty-three year old employee who had held the same position for over fifty years. In this time, Cudd had never received a prior "write-up" about his work until he became a union supporter. ${ }^{20}$ At its Dunean Mill in Greenville, South Carolina, Amos E. Fendley was a model employee who had worked at the company since World War II. Once Fendley became active in the union, however, the company began to make complaints about the quality of his work. He was subsequently discharged for not locking a switch, even though supervisors testified that they had never heard of anybody else being dismissed for this reason. According to the NLRB, managers had simply seized on "an excuse to get rid of Fendley". ${ }^{21}$ Other union supporters were dismissed for engaging in horseplay, taking too long to fetch drinks, and failing to sign "write-ups" that the company had produced. ${ }^{22}$

Workers themselves described how supervisors' attitude to them

ı6. Wesley W. Cook interview, 6-7 April, I978, TWUA Oral History Project, TWUA Papers, tape 5 , side I.

17. I 57 NLRB No. 90, p. 872 .

I8. Ibid., pp. 877,878 .

19. Testimony of the Textile Workers' Union of America before the House of Representatives, Committee on Education and Labor, is March 1976, "House Subcommittee" folder, box 390, ACTWU Papers-Cornell, p. 6.

20. Official Report of Proceedings before the National Labor Relations Board, 29 April 1964, box 260, MSS 396, TWUA Papers, pp. 2193-2195, 2204, 2207.

21. 167 NLRB No. 338, p. 292.

22. Edward Wynne to Arnold F. Ordman, 22 July 1963, "J.P. Stevens and Company Inc. IUD Organizing Campaign - 1963 Roanoke Rapids, North Carolina” folder, box 258, MSS 396, TWUA Papers; Official Report of Proceedings before the National Labor Relations Board, 4 June 1964, box 26I, MSS 396, TWUA Papers, pp. 4849-4850, 4883-4890; 380 F.2d 292 at p. 299. 
changed dramatically once they found out that they had joined the TWUA. In a vain effort to protect its supporters, union organizers mailed their membership lists to the company, but Stevens's executives used the information to harass the most active. "Ever since our names went on the board", commented Greenville worker James Rosemond, "they have been watching our every move, trying to get something on us". ${ }^{23}$ The surveillance took its toll. Stevens worker, Ollie Vernadore, described how her supervisor hid in alleys and behind machines and watched her constantly after she became an active member. "It go on my nerves so bad", she testified, "that I had to go to the doctor". Like many others, Vernadore was subsequently discharged for unsatisfactory work. ${ }^{24}$ Those who were not fired were pressured to withdraw from the union, often by nonunion workers whose activities were encouraged by the company. In one case, anti-union employees were even allowed to reproduce their material in supervisors' offices, using stationery and typewriters provided by Stevens. ${ }^{25}$

The mass discharges and other illegal activities were clearly not simply the actions of a few errant supervisors; rather, as successive NLRB trial examiners concluded, they reflected a company-wide policy to defeat the union's organizing drive even if it meant violating labor laws. ${ }^{26}$ As their firm had been picked out by the TWUA, top managers were determined to vigorously resist. Hal Addis, corporate director for the company's industrial and personnel relations, insisted in 1980 that the union had made a tactical mistake when it had targeted the company in 1963. "They thought J.P. Stevens would fall quickly", he asserted. Other executives shared this feeling. "The union did not believe we would stand up to protect the rights of the employees", insisted Hampton Shuping, a corporate vice-president. ${ }^{27}$ In particular, CEO Robert Stevens was determined to fight the union. TWUA leaders miscalculated when they reasoned that Stevens's high-profile tenure as Secretary of the Army in the

23. Statement of James Rosemond, I2 September 1963, "J.P. Stevens and Company Inc. IUD Organizing Campaign - I963 Tufting Plant (Monaghan), Greenville, South Carolina” folder, box 258 , MSS 396, TWUA Papers.

24. "Official Report of Proceedings before the National Labor Relations Board", 3 I March I964, box 260, pp. 8I 3-81 8, quotation on p. 8i 8 .

25. I 57 NLRB No. 90 at pp. $940-94$ I.

26. In I 965 , NLRB Trial Examiner Horace A. Ruckel noted in Stevens I, which considered charges from both North and South Carolina against Stevens, that, "The record shows close cooperation and a unity of action between the top management at all Respondent's plants, even to the extent of identical posted notices to its employees, identical reply letters to the Union, and the posting of copies on the bulletin boards"; I 57 NLRB No. 90 at p. 943. In 1967, NLRB trial examiner, Boyd Leedom, reached a similar conclusion. See I67 NLRB No. 38 at p. 294.

27. Both in Sharon Bond, "They're Trying To Improve Image”, Greensboro Daily News, 24 February 1980, clipping in the North Carolina Collection clipping file, Wilson Library, University of North Carolina at Chapel Hill, filed under "J.P. Stevens". 
I950s would help their campaign. Unions, the independently-minded New Englander repeatedly insisted, were an unwanted "third party" that would interfere with the direct relationship between managers and their employees. Stevens, who had overseen the relocation of plants from New England to the South, also associated unions with economic ruin, asserting that in the fiercely competitive textile industry management had to keep costs as low as possible in order to prosper. ${ }^{28}$

In response to the union's campaign, supervisors bombarded TWUA supporters with negative material about organized labor. Some were told that union leaders were "racketeers" who caused damaging strikes where workers gained nothing. Company officials expressed their opinion that Stevens would close its mills rather than deal with a union, even though this was a clear violation of US labor law. Other supervisors viewed joining the TWUA as an act of disloyalty, telling union supporters that "you are for an organization that I am against and if you are not for me you are against me". ${ }^{29}$

Managers also made use of the race issue by informing their predominantly white work force of union support for the civil rights movement. In 1965, company officials used their pre-election addresses at two South Carolina plants to tell workers that the recent SelmaMontgomery civil rights march had been partly funded by the labor movement. Workers were also shown a picture of United Automobile Workers' leader Walter Reuther with Martin Luther King. "Do you want your money sent down to Alabama to help support Martin Luther King, help get these niggers out of jail?", managers asked their workers. "When the union members told Walter Reuther they don't want their money sent to help the niggers he told them to shut up." (Reuther's picture was then held up). "Do you want your money to go to Selma, Ala., to help support these niggers and communists and goons and beatniks?" Supervisors and pro-company workers also told workers that if they voted for the union it would result in more blacks coming into their plants. Loom fixer, Harold $\mathrm{Du}$ Bose, even traveled freely through the mills, showing workers a clipping that highlighted union support for the Selma march. On one occasion, Du Bose informed worker Ethel Blakley that "if the union got in,

28. Si Lippa, "Stevens Looks on Union As Third-Party Intruder", Daily News Record, 28 August 1967, "Stevens, J.P. and Co. General Labor, I966-71" folder, box 678, ACTWU PapersCornell.

29. Statement of Robert Carsey, 23 May I963, "J.P. Stevens and Company Inc. IUD Organizing Campaign - 1963 Roanoke Rapids, North Carolina” folder; Statement of Ralph Moore, 3 September 1963, "J.P. Stevens and Company Inc. IUD Organizing Campaign - I963 Tufting Plant (Monaghan) Greenville, South Carolina" folder; "Statement of Betty Ann White", i 8 May 1965, "Betty Ann White" folder; and Statement of Albert Sanders, n.d., "J.P. Stevens and Company Inc. IUD Organizing Campaign 1963 (Dunean Plant)” folder; all in box 258 , MSS 396, TWUA Papers. 
they would pull the niggers in on us, and they would take our jobs". "[T]hat's just the way he said it", she added, "niggers". Following these efforts, the company promoted Du Bose into a management position. Union leaders later blamed the company's use of the race issue as a major cause of their defeats in the two elections. ${ }^{30}$

Across the South, the company's tactics paid off. In I965 and 1966, the union lost every election that it brought at Stevens's plants, and it abandoned other campaigns without even calling for a vote. The discharges were particularly effective because of the time it took for fired workers to be reinstated. Organizers documented how discharges made workers fearful, with many hanging back to see if dismissed employees would actually return. From Great Falls, South Carolina, a dispirited Lawrence Gore noted after a ten-month campaign, "Everybody we contact says they will sign when the fired go back to work. This may take two years if ever. Our activity now is of not much good." ${ }^{1}$ It was December 1967, almost five years after the start of the campaign, before all of the illegally discharged employees were allowed to return, the company having exhausted its legal rights to appeal NLRB decisions. ${ }^{32}$ By this time, the union's campaign had collapsed. In May 1967, the organizing department reported that the Stevens campaign had been "curtailed in recent months", the number of organizers cut to just four. ${ }^{33}$

In the late ig60s and early i970s, these staff carried on limited organizing efforts, but Stevens resisted just as vehemently. In 1968, the union was able to sign up many workers at the company's plant in Statesboro, Georgia, but Stevens responded with a vicious pre-election campaign that wiped out the TWUA's majority. Supervisors threatened

30. Testimony of the Textile Workers' Union of America, AFL-CIO Before the House of Representatives, Committee on Education and Labor, Subcommittee on Labor-Management Relations, is March 1976, "House Subcommittee" folder, box 390, ACTWU Papers-Cornell, p. 8 (first quotation); Official Report of Proceedings before the National Labor Relations Board," I6-i7 August 1965, box 259, MSS 396, TWUA Papers, p. 3 I I (Blakely quotation), pp. 672-682; and Scott Hoyman, "Report of Activities", $5 / 15 / 65$, "Hoyman, Scott" folder, box 683 , MSS 396, TWUA Papers.

31. "Report of Activities", 4/I I/64, all in box 258, MSS 396, TWUA Papers.

32. The move came after the Supreme Court decided on i I December 1967 not to hear an appeal of a lower court's order that the company reinstate the sixty-nine employees held to be have been illegally discharged for union activities. In a statement, Stevens claimed that it would abide by the decision but added that it was confident that its employees "continue to prefer dealing with us in a direct and personal relationship rather than through an outside organization". "J.P. Stevens Acts to Reinstate 69", New York Times, 28 December 1967; George Perkel to Paul Swaity, 25 June 1969; and "Remarks of Robert T. Stevens, President, J.P. Stevens and Co., Inc. Annual Meeting of Shareowners", 4 March 1969; all in "Stevens, J.P. and Co., General Labor, I966-7I" folder, box 678, ACTWU Papers-Cornell.

33. "Southern Region Staff Assignment as of May i 5, 1967", "Department Reports - Executive Council Meeting, Montreal, Canada - May 22-26, I967" folder, box 595, MSS 396, TWUA Papers. 
their employees, telling them that the plant would close if workers voted the union in. "J.P. Stevens", claimed supervisor Bob Stepto, "will throw away this plant just like I am throwing away that nickel". The NLRB set aside the election without a hearing, finding the company guilty of illegal surveillance and unlawful discharges. ${ }^{34}$ Based on its pre-election card majority, the board certified the TWUA as the bargaining agent in Statesboro, but Stevens refused to sign a contract and began to lay workers off. In I975, they finally closed a mill that was only eleven years old. Although the company claimed that its moves were based purely on economics, workers felt that the firm was trying to avoid unionization. ${ }^{35}$

In subsequent votes, the company made extensive use of the Statesboro situation, reminding workers of what could happen if they supported the TWUA. On the eve of a 1972 election at its plant in Turnersburg, North Carolina, the company informed its workers that in Statesboro, the only Stevens mill where the union had won bargaining rights, "a large portion of the machinery and equipment [...] has been standing and out of operation for the last two years. Likewise, the people in that plant frequently have only worked four days a week." Harold McIver, who headed the Turnersburg drive, later blamed these threats of plant closure as the "chief reason" for the TWUA's defeat. ${ }^{36}$ In 1973 , Stevens also won elections in Aberdeen, North Carolina and Walterboro, South Carolina after managers told employees about the declining employment levels at Statesboro. ${ }^{37}$

Following this string of defeats, some TWUA leaders wanted to call off the Stevens campaign. According to some northerners, the union was wasting precious resources on a "no-win situation" and needed to identify more favorable organizing targets..$^{38}$ These voices were in a minority, however. Union leaders decided to fight on, reasoning that they had invested too much in the Stevens campaign to abandon it. They also argued that African-American workers, who were entering the industry in larger numbers, would be more receptive to organizers. African Americans, asserted TWUA strategists, had been radicalized by the civil rights movement and would transform the organizing climate. "The new Black workers", claimed a 1972 report, "have brought with them an awareness of

34. I79 NLRB No. 47, pp. 254-288, quotation on p. 257.

35. Scott Hoyman to Billy R. Smith, 22 July 1975, "J.P. Stevens Statesboro, Georgia” folder, box 648, ACTWU Papers-Cornell; "The Unfair Labor Practices of the J.P. Stevens Company in the Closing of the Statesboro Plant”, i 8 June 1975, "J.P. Stevens Roanoke Rapids North Carolina” folder, box 648, ACTWU Papers-Cornell.

36. W.H. Gray to all employees, n.d., "J.P. Stevens Roanoke Rapids North Carolina" folder; affidavit of Harold McIver, 28 August 1975, "J.P. Stevens July-December 1975" folder, box 647, ACTWU Papers-Cornell.

37. Scott Hoyman to Henry Woicik, 8 July i975; and Harston Fuller et al. to all employees, it August 1974, both in "J.P. Stevens Roanoke Rapids North Carolina" folder.

38. George Perkel interview, 25 and 28 September 1978 and 16 November 1978, TWUA Oral History Project, TWUA Papers, tape 2, side 2. 
the need for cohesive group activity to protect their interests". ${ }^{39}$ In 1973, the union launched a major organizing drive at the company's plants in Roanoke Rapids, where African Americans now made up around onethird of the 3,000 work force. The following year, African-American support played a decisive role as the union won a crucial election. Buoyed by the win, TWUA leaders expanded their organizing efforts. The victory, recalled former organizing director Paul Swaity, "saved the whole drive". $4^{\circ}$

In 1976, the TWUA merged with the Amalgamated Clothing Workers' Union to form ACTWU. A key reason for the merger was the desire of TWUA leaders to create a bigger organization to take on Stevens. Following the Roanoke Rapids election, the company had again steadfastly refused to bargain in good faith, and the new union immediately launched a boycott of Stevens's products that was designed to push the company to sign a contract. At the same time, organizing efforts were stepped up. By November 1977, thirty-three organizers were working on the campaign, and even more were hired in 1978 and $1979 .{ }^{4}$ The new staff still faced a daunting task; at the start of I 977 the company had seventy-five plants in the South, and these were spread out over six states and forty communities. Any union faced a daunting practical challenge in covering all these facilities, and no plant was big enough to have a knock-on effect on others. Most of the mills were also located in small communities where local leaders, afraid of losing their largest employer, had traditionally sided with Stevens..$^{42}$

As organizers began their work, they commonly reported that workers were afraid to talk with them. Not surprisingly, the company's long record of labor law violations had made many wary of signing up. Evan S. Hamilton noted, from a Stevens plant in High Point, North Carolina, that

39. "The Potential for Union Organization in the South", 22 November 1 972, "The Potential for Union Organization in the South" folder, box 3, MSS 97-196, TWUA Papers (Research Department Papers), p. 3 .

40. Paul Swaity interview, is November 1978, TWUA Oral History Project, TWUA Papers, tape 3 , side I.

4I. "Progress Report J.P. Stevens Organizing”, 3 November 1977, “J.P. Stevens Citizens' Committee" file, fiche I of 8, fiche box 7, Murray Finley Papers, held at the Kheel Center for Labor-Management Documentation and Archives, School of Industrial and Labor Relations, Cornell University, [hereafter cited as "Finley Papers"]; General Executive Board Minutes, 26 February 1979, "2/26/79" folder, box 854, ACTWU Papers-Cornell, p. I3. For the TWUA/ ACWA merger and the launching of the boycott, see Daniel, Culture of Misfortune, pp. 272278; George Perkel to Sol Stetin, 24 December 1974, "Stevens, J.P. and Co., General Labor, 1972-4" folder, box 678, ACTWU Papers-Cornell.

42. "The Campaign to Organize J.P. Stevens", ı० February 1977, untitled folder, box 33, Papers of ACTWU's Southern Regional Office, held at the Southern Labor Archives, Georgia State University, [hereafter cited as "ACTWU Papers-Atlanta"]; "J.P. Stevens and Co. Inc.", "Stevens, J.P. and Company General Labor, 1972-74" folder, box 678, ACTWU PapersCornell; I 63 NLRB No. 24 at p. 249. 
the major problem he faced was, "[f]ear as usual". Ernestine Spencer, who was trying to organize a Stevens plant in Laurens, South Carolina, similarly related that, "[o]vercoming fear is the major problem". Workers feared not just dismissal but also supervisors' ability to transfer them to inferior jobs. As organizer, Eddie Nichols, wrote from a failed 1979 campaign in Rock Hill, South Carolina, the major problem that he faced was, "[f] ear that Co. will fire them or put them on a less desired job". All too aware of the Statesboro case, workers also worried that if they voted the union in the plant would close. "Big issue is plant closing", noted organizer Henry Mann in one report. ${ }^{43}$

Managers repeatedly encouraged these fears, counteracting the campaign by posting anti-union flyers on plant bulletin boards. Other material was circulated by pro-company Employee Education Committees (EECs). Funded by business leaders, the committees circulated material that linked unions with economic damage; as one flyer put it, "We know unions cause shut-downs, lay-offs, strikes, and violence. We don't need them!" EECs also warned workers that they could face economic retribution if they did sign a union card. "Those J.P. STEVENS EMPLOYEES who are blindly jumping into the union may not realize the magnitude of their mistake UNTIL THEY APPLY FOR A JOB SOMEWHERE ELSE", warned one flyer. ${ }^{44}$ Anti-union groups also emphasized the costs of union membership, frequently tapping into many southerners' dislike of strong central government: "WE KNOW THAT THE UNIONS ARE ALWAYS AFTER THEIR MEMBERS FOR MONEY...MONEY...MONEY... FOR: DUES, FEES, FINES, ASSESSMENTS, CONTRIBUTIONS, DONATIONS, UNION POLITICAL CAMPAIGNS, ETC. IT'S JUST LIKE ANOTHER GOVERNMENT!!!!!!!!”45

These harsh tactics remained effective. There were, however, other reasons for the union's failure to make real progress in organizing, some of them consequences of ACTWU's decision to launch a high-profile fight against Stevens. Above all, organizers often stressed the difficulties of building interracial support.

In the mid and late I970s, many organizers reported that African

43. Evans Hamilton, "Weekly Organizing Activity Report", I8 August 1979, "Evans S. Hamilton" folder, box 48; Ernestine Spencer, "Weekly Organizing Activity Report", 5 January I980, "Ernestine Spencer" folder, box 50; Edward Nichols, "Weekly Organizing Activity Report", 28 July i979, "Eddie Nichols" folder, box 49; and Henry Mann, "Weekly Organizing Activity Report", 25 August 1979, "Henry Mann" folder, box 49; all in ACTWU PapersAtlanta.

44. "Old Fish and Unions Stink", n.d.; "Caution: Don't Let Anyone Talk You into Signing Your Name on the Union Blue Card", 26 July 1979, both in "Wagram I980" folder, box 29, ACTWU Papers-Atlanta.

45. "WHY PAY HARD EARNED MONEY TO THE UNION?", n.d., "Leaflets and labels" folder, box 29, ACTWU Papers-Atlanta. 


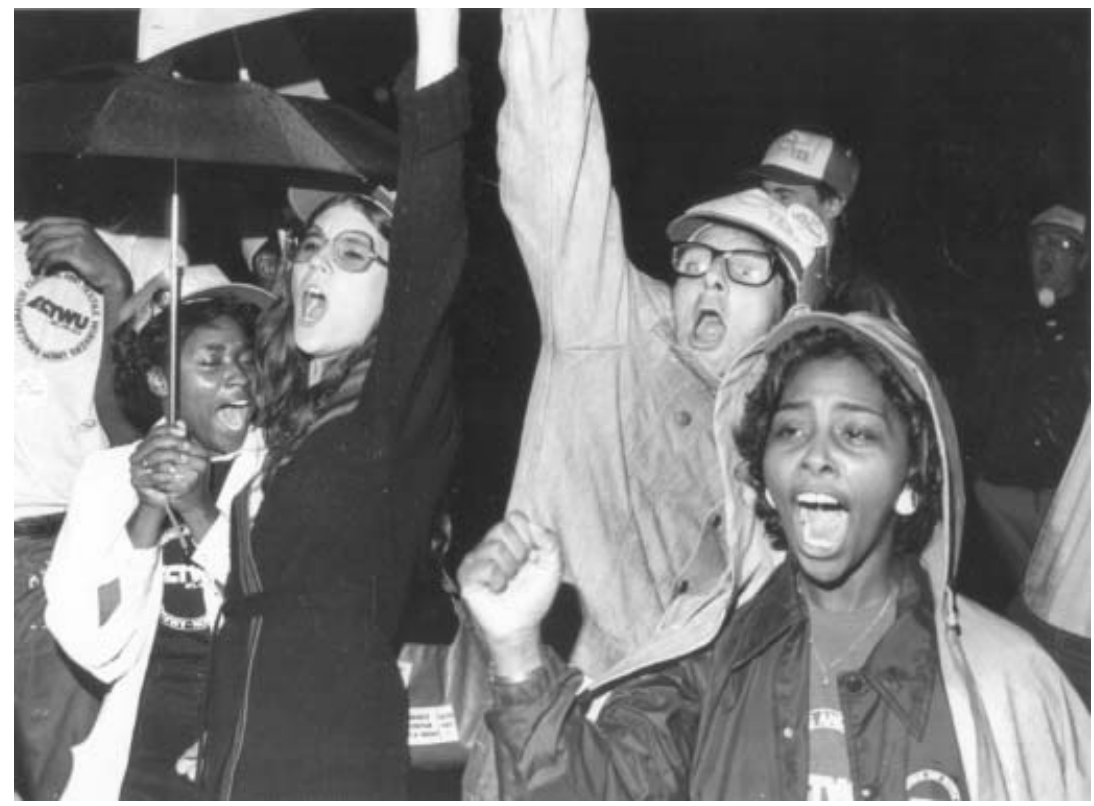

Figure I. Stevens's workers in High Point, North Carolina, one of the sites where the union secured bargaining rights, celebrate the company's decision to recognize the union in 1980. Kheel Center for Labor-Management Documentation and Archives, Cornell University

Americans were, as predicted, responding more enthusiastically to their appeals than whites. Vonnie Hines, who started working on the campaign in 1977 , remembered that blacks consistently welcomed the union more than their white co-workers. "The black workers", she recalled, "seemed to understand more that sticking together meant something, that they could accomplish something by doing that [...] if you went into a campaign where it was predominantly black workers [...] you had more support than you would with a white ratio." 46 African Americans, claimed organizers, had learned from the civil rights movement the importance of working together in order to achieve a common goal. As well as signing cards, they were much more willing to take up committee positions than their white counterparts. In the South Carolina town of Walterboro, organizing director Richard Rothstein typically related that blacks had taken up most leadership positions: "The plant is nearly half black, the committee much more so." 47

Black activism was also problematic for the union, however, because it

46. Vonnie Hines interview with author on 20 February 1996 in Chapel Hill, North Carolina. 47. Richard Rothstein, "Current Campaign Status", 6 November 1978, "J.P. Stevens, Richard Rothstein, 1978-79” folder, box 33 I, ACTWU Papers-Cornell. 
tended to increase white reluctance to join the union. By the late I970s, African Americans made up around 25 per cent of the workforce, ensuring that white support was also needed to secure plant majorities for ACTWU. In many campaigns, organizers complained about the difficulties of signing up whites. At the company's plant in Shelby, North Carolina, Louis Agre faced typical problems. On September 30, 1978 he reported that: "We still have a completely Black committee on 2nd (shift)." Agre's first shift committee was also predominantly black. "There is still a need to build a stronger ist shift committee and to get more White", he admitted. Agre's efforts to address the problem yielded few results. White workers took the lead in opposing ACTWU, and were allowed by the company to pass out anti-union material on company time. Although the experienced organizer tried hard to tackle these problems, the union never succeeded in breaking through in Shelby. ${ }^{8}$

Lack of white support was a problem in several other campaigns. In Laurens, South Carolina, Jimmy E. Smith related that the main problem he faced was "getting white people active". Blacks had signed up to the union in large numbers, causing whites to reason that the union was not "for everybody". ${ }^{49}$ Susan Sachen, who also worked on the Laurens campaign, identified the key obstacle as "[d]eveloping militancy and leadership among white workers". ${ }^{50}$ Similar problems were reported in Pamplico, another small town in the Palmetto state. Here, organizers such as Phillip Pope complained about a "lack of white support" in the plants, which were about 40 per cent black. ${ }^{5 I}$ A summary of the campaign produced by Richard Rothstein highlighted that white inactivity was a serious problem. "Pamplico-Cypress", it noted. "It has not been possible to correct the serious racial inbalance of this campaign by recruiting a significant number of white committee-persons [...] if whites can become involved, this should be a good campaign." The union tried to involve whites, but, as an April I 979 report concluded, "the emphasis continues to be inbalanced". In December 1978, when the union organized a Christmas Party for its supporters, only one white worker attended..$^{2}$

48. Louis Agre, "Weekly Organizing Activity Report", 30 September 1978, box 58, ACTWU Papers-Atlanta. See also Agre’s report for i i November 1978, also in "Lou Agre" folder, box 58 , ACTWU Papers-Atlanta.

49. Jimmy E. Smith, "Weekly Organizing Activity Report", I September 1979, "Jimmy Smith I 979" folder, box 49, ACTWU Papers-Atlanta (quotations). See also Smith's reports for, Is December 1979 and 25 August 1979, both in ibid.

50. Susan Sachen, "Weekly Organizing Activity Report", i 2 May 1979, "Susan Sachen" folder, box 49, ACTWU Papers-Atlanta. See also Sachen's report for i August 1979, ibid.

51. P.R. Pope, "Weekly Organizing Activity Report", 22 October 1977, "Phillip Pope" folder, box 57, ACTWU Papers-Atlanta.

52. Richard Rothstein Memorandum, 5 March 1979, "JPS - Richard Rothstein 1978-1980" folder, box 33 I, ACTWU Papers-Cornell; Richard Rothstein to Harold McIver, ro April I979,

"Richard Rothstein, 4/2/79-5/25/79" folder, ibid. 
The same problems were reported elsewhere. Staff in Wagram, North Carolina, another major target, found whites giving them a wide berth. As Donna Krenik put it, "we are having awful time with whites". On one report, in response to the question "What major problems does campaign at this plant present to you?", Krenik simply wrote, "Whites". In Milledgeville, Georgia, meanwhile, drive leader, Mel Tate, wrote that the campaign needed "more white involvement" to be successful. Black workers in the small Georgia community had responded enthusiastically to the efforts of black organizer James Orange, but whites had not followed suit. 53

Although the union won the Roanoke Rapids election, its support was also racially unbalanced. African Americans were much more likely to hold union cards, and organizers only secured just enough white support to eke out a narrow victory. In the eastern North Carolina town, as elsewhere, some whites clearly stayed away from ACTWU for racial reasons. White worker, Wilson Lambert, commented in 1977 that he was opposed to the union because it supported "nigger rights". "It seems to me", he added, "that the ones you get at the union hall are colored". Kermit Smith also associated the union with black rights. "I believe", he commented, "because the Union is about eighty-five per cent black people, that they have been promised - or maybe they tend to believe more what they're promised, I don't know what it is - but they have been promised a lot of things that the Union cannot possibly deliver." 54 Other white textile workers were candid about their own difficulties in accepting blacks into nontraditional positions. "We were slow to really accept that black people could work their way up to supervision and stuff like that", noted one North Carolina worker, "and I know a lot of people that resented a black man being over them".55 In the i960s and I970s, the pace of racial change certainly appeared rapid to whites that were used to working in an overwhelmingly white industry. Between 1962 and I966, the proportion of black textile workers almost doubled (from 4.6 per cent to 8 per cent) and it continued to rise quickly over the next decade. ${ }^{56}$ By the late I970s, the

53. Mel Tate, "Weekly Organizing Activity Report", 27 October 1977, "Mel Tate" folder, box 57; Donna Krenik, "Weekly Organizing Activity Report", 27 October 1979, "Donna Krenik" folder, box 49; both in ACTWU Papers-Atlanta.

54. Lambert quoted in "Target J.P. Stevens", Sixty Minutes, March 1977; Smith quoted in "J.P. Stevens", The MacNeill/Lebrer Report, 22 December 1976, copies held at the Kheel Center for Labor-Management Documentation and Archives, School of Industrial and Labor Relations, Cornell University.

55. Elboyd Deal interview with author on I I March 1996 in Kannapolis, North Carolina.

56. "Profile of Personal Characteristics of American Textile Workers", 24 November 1967, "Dept. Reports - Executive Council Meeting, Bal Harbor, Florida - December 2-5, 1967" folder, box 595, MSS 396, TWUA Papers. 
proportion of blacks in the industry was consistently greater than it was for manufacturing industry as a whole. ${ }^{57}$

Organizers rarely discussed the reasons for white reluctance to sign cards, content to note its existence instead. In recent years, scholars such as Michelle Brattain and Bryant Simon have shown that there were many reasons for white workers to be hostile to blacks, with the plant experience often reinforcing a deeper commitment to racial antagonism. As well as being excluded from production jobs, blacks had been barred from company-owned mill villages, often confined instead to smaller houses on the fringes of textile communities. ${ }^{8}$ In many textile towns, integration was taking place in schools and other areas of community life at the same time that it was occurring in the mills, and many whites struggled to adjust to a new way of life. Whites who were reluctant to participate in heavily black unions also withdrew from public spaces when blacks were admitted. Many stopped using public facilities such as water fountains and cafeterias once they were integrated. White southern textile workers often employed black women as domestics in their homes, and they also feared that if these women got jobs in the mills, they would no longer be able to recruit such help. 59

At the same time, white reluctance to join the union was also partially a reflection of their different experiences within the industry. As white workers generally had more seniority than blacks, most had direct experience of previous union failures and treated organizers with circumspection. As one organizer reported, white workers told her that they were "not willing to get active for ANOTHER campaign". Some had bitter memories of lost strikes, including the 1934 debacle. As whites tended to be older than the new black recruits, they were more likely to reason that they would accept the status quo for a few more years until they reached retirement. Reporting on his difficulties in recruiting older whites, Louis Agre added, "It is hard to get someone active with one and a half years to go to retirement." 60

These differing responses to the union's campaign were also a reflection of the fact that African-American workers continued to face discrimination in the plants and looked to ACTWU to give them better job opportunities. At Stevens's mills, blacks had made progress into production jobs in the late I960s and early I970s, yet the highest-paid positions

\section{7. "J.P. Stevens", The MacNeill/Lehrer Report.}

58. Brattain, The Politics of Whiteness, pp. 3-10; Simon, A Fabric of Defeat.

59. Kathleen Hope Curry, "Weekly Organizing Activity Report", 5 February 1977, box 57, ACTWU Papers-Atlanta; B.J. Gordon interview with author on i I April 1996 in Andrews, South Carolina; Minchin, Hiring the Black Worker, pp. IоI-104.

60. Kathleen Hope Curry, "Weekly Organizing Activity Report", I 2 March 1977, box 57, ACTWU Papers-Atlanta; Salmond, The General Textile Strike, p. 239; Louis Agre, "Weekly Organizing Activity Report”, 9 December 1978, box 58, ACTWU Papers-Atlanta. 
remained overwhelmingly white. In I969, African-American men held just 2.9 per cent of skilled craft jobs in the Roanoke Rapids mills, even though they had secured over 30 per cent of semiskilled jobs. The lower-paid the job, the more black it was; in I969, for example, black men still held over 90 per cent of the "service" positions. ${ }^{61}$ Disgruntled African Americans turned to filing charges with the Equal Employment Opportunity Commission (EEOC), set up to monitor compliance with Title VII of the 1964 Civil Rights Act, which prohibited discrimination in employment. By August 1975 the Commission had received 178 charges of Title VII violations against J.P. Stevens alone. ${ }^{62}$ In the early i970s, AfricanAmerican workers at several Stevens plants also joined together to launch major class-action racial discrimination lawsuits under Title VII.63 Disproportionately assigned to lower-paying jobs, many blacks felt that they had less to lose by supporting the union. As ACTWU member Sammy Alston recalled,

I don't think we had nothing to lose because the only thing he could do was fired you, that's all, and you couldn't have went no lower because you was working at the last level right there, and they constantly come and hired people over the top of you, come in there and create jobs for people. ${ }^{64}$

In contrast, white workers still monopolized the best positions in the mills and had more to lose if they were fired or demoted by the company. These problems were described in many campaigns. In Milledgeville, Georgia, ACTWU's Robert Tim Brown related that "Most of the support for the campaign comes from the black employees; the whites well recognize their superior position in the plant and are extremely difficult to organize."6s In addition to holding better-paying positions, whites were also much more likely to work on the more desirable first or second shifts. Joe P. Moody, a Roanoke Rapids civil rights activist whose wife worked at J.P. Stevens, recalled that, "most white people was on first, some was on second $[\ldots]$ and most of your black was on second and third $[\ldots]$. They

6r. "The Company's Reports to the US Equal Employment Opportunity Commission", (Plaintiff's Exhibit 90), filed in Sledge et al. vs J.P. Stevens (United States District Court, Eastern District of North Carolina, I970), p. 30, records held at the United States District Court, Eastern District of North Carolina, Raleigh, North Carolina.

62. George Perkel to Henry Woicik, 5 August 1975, "J.P. Stevens July-December 1975" folder. 63. In addition to the Sledge case, black workers also brought class action suits against Stevens's plants in Stanley, North Carolina and Abbeville, South Carolina. See Minchin, Hiring the Black Worker, pp. 4, III-II2, I35-I37, I47-I48.

64. Sammy Alston, interview with author on 9 February 1996 in Roanoke Rapids, North Carolina.

65. Robert Tim Brown to Arthur M. Goldberg, 23 August 1976, "JPS Milledgeville, Georgia" folder, box 22, ACTWU Papers-Atlanta; Joe P. Moody interview with author on I 2 March 1996 in Roanoke Rapids, North Carolina. 
always stayed on low-paying jobs like sweeping and all that kind of stuff, so up where the money was no black was up there."66

Whites therefore stayed away from the union not simply because of ideological racism but because of the economic advantages that segregation had provided them in the southern textile mills. Conversely, some were willing to join with blacks when they had an economic motive for doing so. During the Roanoke Rapids campaign, the union initially struggled to secure white support, but was ultimately able to win the election largely because many whites were dissatisfied with their declining payouts from the company's profit-sharing plan. Caused by a weak stock market, the most affected by the dip were older white workers, who had traditionally opposed the union. African-American union supporter, Bennett Taylor, remembered how this economic issue breached the racial divide. "Back then", he recalled,

[...] we had what you call a profit-sharing plan [...] the older white workers couldn't understand [...] they couldn't understand how do my statements show up a decrease. [...] I was in-plant organizer in my plant, which is Roanoke Fabricating Plant, and I started using it to our advantage. I said 'Look [...] I said once we vote the union in, negotiate a contract, we're going to negotiate a pension plan that the company contribute to that is going to show an increase every year'. [...] When you start talking facts like that, whether you're black or white, you know, people understand when you start taking my money ${ }^{67}$

In the wake of the Roanoke Rapids election, Stevens guaranteed that workers' pay-outs would steadily increase regardless of stock-market fluctuations. TWUA strategists realized that this change would hurt their efforts, especially as it was publicized just before an election at the company's mills in Wallace, North Carolina. "The purpose of the announcement", wrote union attorney Henry Woicik, "virtually on the eve of the Wallace election, was to thwart TWUA's organizing of the Stevens chain". ${ }^{68}$ In Wallace, in fact, the union drew around 75 per cent of its support from blacks but it was unable to secure enough white backing to prevail in the election. ${ }^{69}$

In the 1970s, Stevens increasingly sought to undercut the union's economic appeal, showing that the firm did not simply rely on intimidating its workers. Throughout the decade, the company granted annual wage increases and was careful to match the wage levels of unionized textile plants. As organizer Verney L. Cumbee related, "the

66. Ibid.

67. Bennett Taylor interview with author on 9 February 1996 in Roanoke Rapids, North Carolina.

68. Henry Woicik to Sol Stetin, 26 February 1975, "J.P. Stevens January-June 1975” folder.

69. Paul Swaity interview, TWUA Oral History Project, TWUA Papers, tape 3, side 2; National Observer, 6 October 1973, clipping in "Remarks of Senator Edward M. Kennedy, October 4, 1973", Congressional Record; "Stevens J.P. and Company General Labor, I972-74” folder. 


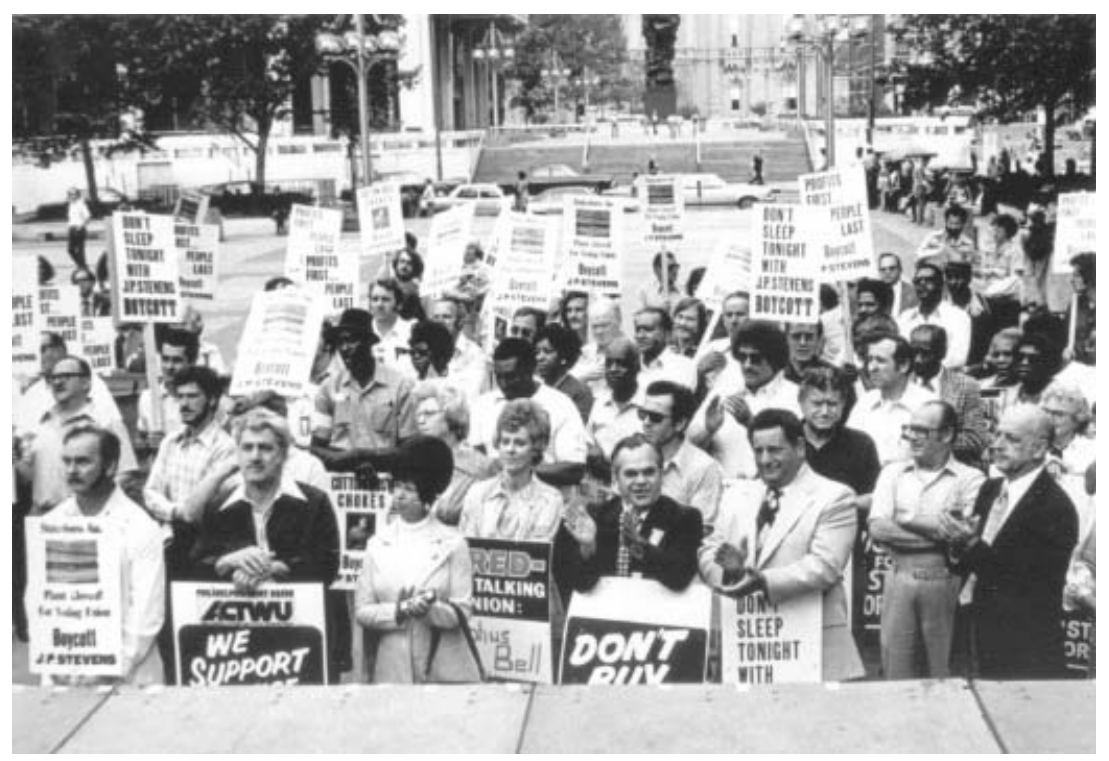

Figure 2. Union supporters in Philadelphia, at the height of the boycott.

Photo Associates/Kheel Center for Labor-Management Documentation and Archives, Cornell University

company tell people that they don't need a union because they have the same as the union plant have now". ${ }^{\circ}$ The company also made improvements in its fringe benefits. In the summer of 1978, Stevens made Christmas Eve a paid holiday and increased workers' vacation benefits, both moves that concerned ACTWU strategists. ${ }^{71}$ Anti-union workers often reasoned that the company was treating them reasonably by steadily increasing their wages. As Roanoke Rapids worker, Opal Nethery, commented in 1976: "Now, we have had increases in our salaries from time to time throughout the fifteen years that I've been working, and I consider them reasonable increases. And I've been perfectly satisfied with mine." 72

This shift in the company's tactics should not be overstated, as Stevens continued to rely on its traditional moves of firing and intimidating union supporters. Just as it had in the past, the company also linked unions with

70. Verney L. Cumbee, "Weekly Organizing Activity Report", 22 December 1979, "Verney Cumbee" folder, box 48, ACTWU Papers-Atlanta.

7r. "J.P. Stevens and Co. Inc Position Paper", i June 1979, untitled folder, box 58, ACTWU Papers-Atlanta; Richard Rothstein to Scott Hoyman, is June 1978, "J.P. Stevens Richard Rothstein, $1978-79$ " folder.

72. Quoted in “J.P. Stevens”, The MacNeill/Lehrer Report. 
plant closures, violence, and economic insecurity. "UNION DEMANDS destroy companies", claimed one flyer. "IT'S TRUE. YOU KNOW IT. Don't take a chance with your JOB." In 1976-1977, ACTWU asserted that Stevens fired twenty-nine workers in order to halt union activity. Compared to the early i960s, the number of discharges had decreased, although this was partly because the union was contesting fewer elections. ${ }^{73}$

While Stevens's response to the campaign remained important, some of the problems faced by the union were a consequence of its own decisions. The boycott and corporate campaign clearly hurt the drive, as the company repeatedly told its employees that ACTWU's efforts would wipe out their jobs. "The union and the leaders of Big Labor", claimed Stevens CEO, James D. Finley, "are openly trying to destroy our Company and with it the jobs of 45,000 people. Their actions indicate that they have no concern for Stevens employees". ${ }^{74}$ The boycott, admitted union strategists, made organizing "more difficult", but they insisted that the tactic was necessary because it was impossible to strike effectively against such a large firm..$^{75}$ Aware that the company would use the boycott against it if it called elections, the union instead tried to get a majority of workers in each plant to sign cards. In the late I970s, this strategy was closely tied to AFL-CIO efforts to secure passage of a labor reform bill that would allow the NLRB to give unions bargaining rights based on card majorities. Although it passed the House by a large margin in the spring of 1978 , a successful filibuster by Senate conservatives killed the AFL-CIO bill, derailing ACTWU's strategy. Following this, ACTWU leaders still refused to authorize votes because they remained afraid that the company would launch vicious pre-election campaigns. In several locations, pro-union workers became consequently frustrated. "Having gained majorities or near majorities in a number of plants a good deal of staff time must be spent in maintaining the interest, loyalty and involvement of the workers", noted an overview report. ${ }^{76}$

73. “The J.P. Stevens Company: Human Rights in 1977”, “J.P. Stevens Human Rights Report I978 - Si Kahn" folder, box 366, ACTWU Papers-Cornell; "Question - WOULD THE UNION CLOSE YOUR PLANT?”, "Leaflets and labels” folder, box 29, ACTWU PapersAtlanta.

74. James D. Finley to All Stevens Employees, 3 I January 1977, untitled folder, box 33, ACTWU Papers-Atlanta.

75. Paul Swaity to President Finley et al., is June 1976, "J.P. Stevens Correspondence" file, fiche 2 of 7 , fiche box 7, Finley Papers.

76. "Watch Out for 'Stevens Bill' and Attack on R-T-W Laws", Labor Analysis and Forecast, 2 1:9 (r May 1977), in "J.P. Stevens - Newspaper Clippings" folder, box 34, ACTWU PapersAtlanta; Archie Robinson, George Meany and His Times (New York, 1981), pp. 377-378; "Progress Report J.P. Stevens Organizing”, 3 November 1977, “J.P. Stevens Citizens' Committee" file, fiche I of 8, fiche box 7, Finley Papers. 
Other strategic decisions also hurt the drive. As part of its efforts to secure labor law reform, ACTWU worked with the AFL-CIO to publicize Stevens's lawlessness. While this campaign secured positive media coverage for the union, it also hurt organizing. ${ }^{77}$ Staff noted privately that the company's notorious reputation only increased unorganized workers' fear. In March 1979, organizing director, Richard Rothstein, acknowledged "the past difficulties we have had in reconciling a focus on Stevens repression and lawlessness with the need to inspire confidence and hope in unorganized workers". ${ }^{78}$

Union leaders also found it hard to maintain morale among their own staff. The organizers' job was demanding and difficult. As their reports highlight, organizers worked long hours for a meager salary and had to travel vast distances in order to reach scattered textile plants. Not surprisingly, turnover was a constant problem. Organizers frequently clashed with their superiors. The union's policy of only allowing organizers to go home every other weekend was particularly unpopular. Other staff complained about delays in receiving their travel expenses, which they had to pay up-front. There were also conflicts between campaign directors Harold McIver and Richard Rothstein, with Rothstein disliking McIver's influence over staff in the field. These disagreements were largely a reflection of the fact that the campaign had two directors and they inevitably competed for control; amalgamating the position or establishing a clearer chain of command seemed the obvious solution. ${ }^{79}$

While the union's organizing efforts stuttered, other parts of its campaign were more successful. The corporate campaign pressured several Stevens directors, often the head of companies with union links, to resign. While it only had a mild impact on sales, the boycott secured backing from a wide range of church groups, civil rights activists, and feminist organizations. Taking control of the company at the start of I980, new CEO, Whitney Stevens, was keen to reach a truce. After several months of secret talks, the two sides agreed to a contract that covered Roanoke Rapids and two smaller sites that the union had organized. The contract included the check-off of union dues and the arbitration of disputes, both key stumbling blocks in the past. In forcing the company to deal with the union, ACTWU had clearly won an important point of principle.

77. Gail Jeffords to Murray Finley et al., 30 June I980, "Kleeper - Public Relations J.P. Stevens" file, fiche I of 4 , fiche box 7, Finley Papers.

78. Richard Rothstein to Sol Stetin, I2 March 1979, "J.P. Stevens Richard Rothstein I980" folder.

79. Fred Nye to Jack Goldstein, 7 February 1978, "Fred Nye" folder, box 56, ACTWU PapersAtlanta; Howard Brown to Sol Stetin, I9 December 1979, "J.P. Stevens Richard Rothstein, 1978-79" folder; Rich Rothstein to Jack Sheinkman, I 9 February 1979, "Richard Rothstein, 4/2/ 79-5/25/79" folder; and Harold McIver and Richard Rothstein to Sol Stetin, I 2 July 1978, "J.P. Stevens Richard Rothstein, 1978-79" folder; all in box 33 I, ACTWU Papers-Cornell. 
Proclaiming a "major breakthrough", its leaders hoped that they could now make further gains at other Stevens plants. ${ }^{80}$

In the aftermath of the settlement, the union carried on its organizing efforts, yet they yielded few results. Although company officials recognized ACTWU at the three unionized sites, they still vigorously opposed ongoing organizing efforts. The company also continued to pay its union and nonunion workers the same. "The settlement", concluded organizer John Barry, "makes clear that wages and benefits are the same in unorganized as in organized plants. Whether we like it or not, money talks." As a result, the union could no longer promise to deliver "something better". ${ }^{8}$ Inion efforts were disappointing; as ACTWU President, Murray Finley, admitted in January I98 I, "We still have not found the key to a major breakthrough in organizing." 82 The union certainly could not be faulted for lack of effort, and as late as July 1982 it was still spending more than 50 per cent of its overall budget on organizing. Between 1977 and I983, ACTWU operated in the red and financial restrictions eventually pushed its leaders to close down the Stevens drive. Under an agreement reached in October 1983, the company agreed to pay the union \$I million in order to settle outstanding unfair labor practice charges. In return, the union terminated all other board cases that it had pending. A twenty-year war had finally ended. ${ }^{83}$

By the time of the settlement, both the union and Stevens recognized that the textile industry was suffering severe economic problems. The two foes even joined forces in lobbying politicians for more protection from imported textiles. Like other US textile companies, Stevens responded to the import threat by closing plants. In 1977, at the height of ACTWU's

80. Hodges, "J.P. Stevens and the Union", pp. 6I-62; Warren Brown, "Great Labor War Gains Tallied", The Washington Post, 26 October I980, p. A I4; Del Mileski, "Status Report on the J.P. Stevens Boycott", 5 June 1978, "Status Report I" folder, box 40I, ACTWU Papers-Cornell; Philip Shabecoff, "Stevens Pact Is Ratified, Encouraging Unions in South", New York Times, 20 October I980, pp. A I, I6. At the time, Murray Finley told the union's executive board that "our union has made a major breakthrough in the South"; "Meeting of the General Executive Board", I9 October 1980, “GEB Minutes 2/23/8I; I/7/8 I; 10/19/80" folder, box 1005, ACTWU PapersCornell, p. 2.

8 I. John Barry, “Report on J.P. Stevens - Wagram, NC”, i 8 March i98 I, "Wagram” folder, box 29, ACTWU Papers-Atlanta. For the company's reaction to the settlement, see Hal Taylor, "Stevens-ACTWU Shape Up Comprehensive Agreement", Daily News Record, 3 I July i980, clipping in "J.P. Stevens I 980-" folder, box 104, ACTWU Papers-Cornell.

82. "Meeting of the General Executive Board", 7 January I98 I, "GEB Minutes 2/23/8I I I/7/8 I; I0/19/80" folder, box 1005, ACTWU Papers-Cornell, p. 2.

83. "NLRB Clears Settlement of J.P. Stevens Charges", Daily Labor Report No. 204 (20 October 1983), "J.P. Stevens ACTWU Press Release 10/83 NLRB Settlement after Twenty Years" folder, box 628, ACTWU Papers-Cornell; "Meeting of the General Executive Board", 27-30 July 1982, "GEB Minutes 7/27/82; 5/20/82" folder, box 1005, ACTWU Papers-Cornell, p. 7; "Meeting of the General Executive Board" 5-8 March I984, "GEB Minutes 9/29-30/83; 8/ $5-8 / 84 ; 5 / 1-3 / 84 ; 6 / 4 / 84-6 / 6 / 84$ ” folder, box I005, ACTWU Papers-Cornell, p. I6. 
campaign, the firm employed 44,100 Americans, but this fell dramatically to 23,400 in $1987 .{ }^{84}$ In 1987 , the company issued what was to be its final annual report. In it, they noted that imports had risen to a new record for the sixth consecutive year and posed "the industry's continuing and most tenacious problem".85 The following year, Stevens disappeared as a corporate entity, divided up into three separate companies after being purchased by competitor West Point Pepperell. ${ }^{86}$ Over the course of the I990s, the textile industry continued to decline, especially in the wake of the 1994 North American Free Trade Agreement, which encouraged lowwage industries to relocate to Mexico. Between 1997 and 2002, 236 textile plants shut down in the Carolinas alone, at the cost of 75,000 jobs. In 2002, the industry's worst since the Great Depression, 62 Carolina mills closed their doors. ${ }^{87}$

The industry's decline robbed ACTWU of the finances that it needed to fund major organizing efforts. As mill after mill closed, the union increasingly switched to organizing in more economically vibrant industries. ${ }^{88}$ Even if the industry had not declined, however, it is unlikely that major organizing gains would have followed the Stevens campaign; despite extensive efforts, the union had not been able to organize more than a small portion of the company's workers, and they had been unable to establish a union wage differential. Ultimately, the union's failure to organize Stevens was a reflection of more than simply the company's lawlessness. In particular, the union's difficulties in building interracial support severely hampered its efforts. As other scholars have pointed out, the color line severely inhibited efforts to build interracial unions in the South. While some critics have suggested that unions should have been more responsive to black militancy, the Stevens campaign shows that efforts to build campaigns around black activism did not provide an easy solution to labor's weakness in the South, especially as most industries contained white majorities. Recruiting whites was difficult, especially

84. "J.P. Stevens Annual Report 1977", "J.P. Stevens and Company Inc. Annual Reports, 1967I981" folder; "J.P. Stevens Annual Report 1987", "J.P. Stevens and Company Inc. Annual Reports, I982-1988" folder.

85. "Stevens Annual Report 1987", "J.P. Stevens and Company Inc. Annual Reports, I982I988" folder.

86. Hodges, "J.P. Stevens and the Union", p. 62; Robert J. Cole, "Pepperell Agrees to Farley Offer", New York Times, 24 February 1989, pp. Di, Di 3.

87. Charles Lunan, "Empty Mills Burden Carolinas", Charlotte Observer, 22 July 2002, clipping in the North Carolina Collection clipping file, Wilson Library, University of North Carolina at Chapel Hill, filed under "Textile mills"; Zieger and Gall, American Workers, p. 263. 88. In I995, ACTWU merged with the International Ladies Garment Workers' Union to form the Union of Needletrades, Industrial, and Textile Employees (UNITE). In recent years, UNITE has increasingly organized outside the declining textile and apparel sectors. 
when they saw little economic imperative to join with their black coworkers. ${ }^{89}$

In many ways, the Stevens campaign had an important influence on US labor relations. In its struggle with the textile giant, ACTWU launched the very first corporate campaign, providing a model that has been copied by others in subsequent years. In the I980s, Ray Rogers, the maverick activist who first came to prominence during the Stevens battle, coordinated several similar efforts. Since the early i 980 s, many employers have also copied the tactics that Stevens pioneered, deliberately violating labor laws in order to thwart organizing efforts. In the late I970s, the AFL-CIO tried to use the Stevens case to bolster its efforts to reform labor law, yet the failure of these efforts made it easier for other companies to ape Stevens's tactics. In the I980s and I990s, it was common for companies to kill organizing drives through selective discharges of union supporters, just as Stevens had done; in I980 at least one of every twenty workers who voted for a union in an NLRB election was dismissed. In many ways, Stevens' tactics helped pave the way for the widespread corporate attack on organized labor that occurred in the I980s and early I990s, an onslaught that gravely weakened the US union movement. ${ }^{90}$

89. For the argument that unions could have made more progress in the South if they had been more responsive to black workers, see Honey, Southern Labor and Black Civil Rights; Robert Korstad and Nelson Lichtenstein, "Opportunities Lost and Found: Labor, Radicals, and the Early Civil Rights Movement,” Journal of American History, 75 (I988), pp. 786-8 I I; Michael Goldfield, "Race and the CIO: The Possibilities for Racial Egalitarianism During the 1930 and I940s”, International Labor and Working-Class History, 44 (Fall I993), pp. I-32. For opposing views, see Alan Draper, Conflict of Interests: Organized Labor and the Civil Rights Movement in the South, 1954-I968 (Ithaca, NY, I994); Zieger, The CIO; Bruce Nelson, "CIO Meant One Thing for the Whites and Another Thing for Us': Steelworkers and Civil Rights, 1936-1974”, in Zieger, Southern Labor in Transition, pp. I I3-I45; and William P. Jones, "Black Workers and the CIO's Turn Toward Racial Liberalism: Operation Dixie and the North Carolina Lumber Industry, 1946-1953", Labor History, 4I (2000), pp. 279-306. Important studies of interracial unionism include Daniel Letwin, The Challenge of Interracial Unionism: Alabama Coal Miners, I878-I92 I (Chapel Hill, NC, I998); Eric Arnesen, “'Like Banquo’s Ghost, It Will Not Down': The Race Question and the American Railroad Brotherhoods, I880-1920", American Historical Review, 99 (1984), pp. I60I-1633. For good summary of the literature on southern unions and race, see Brattain, "The Pursuits of Post-exceptionalism”, pp. I-46.

90. Zieger and Gall, American Workers, pp. 240-270; Tom Juravich and Kate Bronfenbrenner, Ravenswood: The Steelworkers' Victory and the Revival of American Labor (Ithaca, NY, 1999), esp. pp. 69-72; Timothy J. Minchin, Forging a Common Bond: Labor and Environmental Activism in the BASF Lockout (Gainesville, FL, 2003); Stephen H. Norwood, Strikebreaking and Intimidation: Mercenaries and Masculinity in Twentieth-Century America (Chapel Hill, NC, 2002), p. 247. 